\title{
Nurse Support on Health Cadre Empowerment and the Influence on the Ability of Women's Mentoring Human Immunodeficiency Virus/Acquired Immune Deficiency Syndrome
}

\author{
Ernawati Ernawati $^{1,4 *}$, Nursalam Nursalam ${ }^{2}$, Shimarti Rukmini Devy ${ }^{3}$, Edy Soesanto $^{4}$, Sri Rejeki $^{4}$ \\ ${ }^{1}$ Student, Doctor on Nursing Study Programmed, Faculty of Nursing, Airlangga University, Surabaya, Indonesia; ${ }^{2}$ Department of \\ Nursing, Airlangga University, Surabaya, Indonesia; ${ }^{3}$ Department of Public Health, Airlangga University, Surabaya, Indonesia; \\ ${ }^{4}$ Department of Nursing and Health Sciences, Universitas Muhammadiyah, Semarang, Indonesia
}

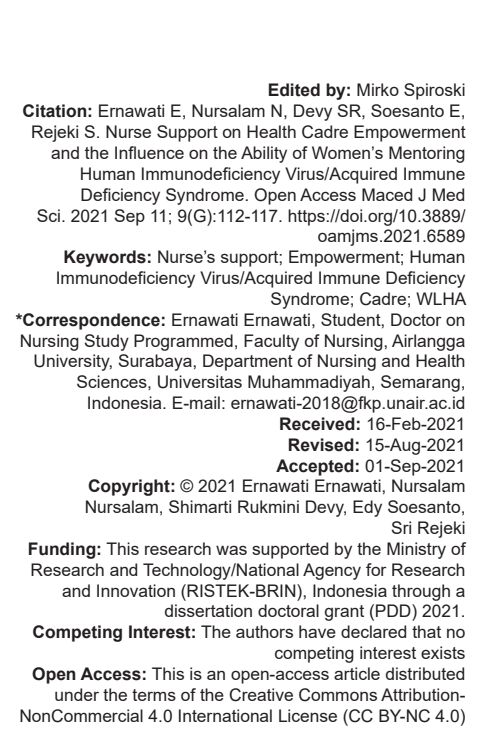

\begin{abstract}
BACKGROUND: In the context of community empowerment, the role of nurses as health workers is very important to transform the knowledge and skills of cadres. However, the support of nurses in empowering human immunodeficiency virus/acquired immune deficiency syndrome (HIVIAIDS) health cadres has not been widely explained.

AIM: This study examines the effect of nurse support and empowerment on the ability of HIVIAIDS cadres to assist mothers with HIV/AIDS.

METHODS: This study used a cross-sectional approach. We involved 119 HIV/AIDS cadres including local residents who care about AIDS (WPA, $n=90$ ), facilitators of families of hope (PKH, $n=17$ ), and peer support groups (KDS, $n=12$ ). Data collection was carried out from February to April 2020, the sample was selected using multistage cluster sampling in Kudus Regency, Central Java, Indonesia. Multiple linear regression analysis was conducted to determine the support of nurses, empowerment of HIV/AIDS cadres, and its effect on the ability of cadres in assisting women with HIVIAIDS.

RESULTS: We found that nurses' support for the empowerment of HIV/AIDS cadres was low in almost all aspects (instrumental, informational, emotional, and affiliation). Nurse support and cadre empowerment affect the ability of HIVIAIDS cadres by $28 \%$. Regression test formula $Y=-97.080+0.738 X_{1}+1.944 X_{2}$.

CONCLUSION: The results showed that the four types of nurse social support may be interrelated and are generally still low in the process of empowering HIV/AIDS cadres. There is an effect of nurse support and empowerment of
\end{abstract} HIVIAIDS cadres on the ability of cadres to assist women with HIVIAIDS.

\section{Introduction}

Human immunodeficiency virus/acquired immune deficiency syndrome (HIVIAIDS) cadres as community nurse partners mobilize residents and communities. They serve in an effort to help deal with HIV problems. The presence of cadres addresses the shortage of health workers in low- and middle-income countries. This is due to unequal distribution and the need to accelerate progress toward universal health. Globally, there are more than 5 million community health workers who are active and proven effective in providing services to the community [1]. In addition, community involvement in various health problem management programs has saved a lot of costs [2].

Cadre involvement occurs when there is sensitivity to the various needs of people living with HIV/ AIDS (PLWHA) as a vulnerable group in society. This level of engagement can evolve from simply receiving information, consultation, collaboration, and control [3]. Cadre activities include providing information to the community as well as community outreach which is a systemic problem that occurs in a weak health system [3], [4]. Studies show that health cadres have succeeded in increasing access to health-care services, improving programs to prevent HIV transmission among women, and reducing HIVIAIDS mortality [5], [6].

In Indonesia, community participation in HIV and AIDS prevention efforts has been regulated in the Minister of Health Regulation No. 21 of 2013. The policy on HIV and AIDS prevention is stated in article 51 paragraphs 1 that the community participates include: (1) Promoting healthy living behavior; (2) increasing family resilience; (3) preventing stigma and discrimination against HIV-infected people and their families; (4) forming and developing local residents who care about AIDS; and (5) encourage community members who have the potential to carry out risky acts of contracting HIV to check themselves into 
voluntary counseling and test service facilities. The community needs to be empowered through a series of interventions to increase the capacity of themselves or groups [3].

The elements of HIVIAIDS health cadres in the Kudus district consist of peer support groups (KDS), AIDS care residents (WPA), and family hopeful program companions $(\mathrm{PKH})$. Each element of the HIVIAIDS cadre has a different history. PKH cadres are social assistants to poor families or beneficiaries. Its main task is to mediate, facilitate, and advocate for changes in family behavior. They are recruited and received salary compensation by the Ministry of Social Affairs with a Decree of the Director General of Social Protection and Security. KDS cadres were formed at the initiation of fellow HIVIAIDS sufferers as a social community to share life experiences. The majority of KDS cadres are volunteers without salary compensation, but three of them were recruited by the Kudus district health office as outreach workers and assistants for PLWHA. They raise solidarity and help each other with fellow PLWHA sufferers. Meanwhile, WPA cadres are a form of public participation in HIVIAIDS health issues, volunteers without salary compensation. The formation of cadres was initiated by a non-governmental organization.

Nurses have the competence to strengthen service programs related to HIVIAIDS, oversee policy and regulatory reform in the context of task transfer, division of tasks, and the scope of nursing practice [7]. Nurses develop empowerment of HIVIAIDS health cadres with partnerships as an effort to deal with the problems of the HIVIAIDS epidemic.

Empowerment is understood as an outcome and as a "mediator." Transformation occurs when a good relationship (right relationship) between one and more levels of the human system and nurses as agents of change promotes care without judgment [8]. Good relationships are defined as all organizational patterns in the system that supports, encourages, enables, or produces transcendence and self-actualization [9]. If a good relationship is not established, then the potential of community members to participate consciously in change cannot be fully empowered. Previous research suggested the philosophical model of health cadre empowerment by building community health services as partners [10]

In the context of community empowerment, the role of nurses as health workers is so important to transform the knowledge and skills of cadres. Various supports are needed to improve the capacity of cadres in assisting and assisting the needs of women with HIV/ AIDS in their area. However, how much nurse's support in empowering HIVIAIDS cadres is not widely known. This study aims to determine the effect of nurse support and cadre empowerment on the ability of HIVIAIDS cadres to assist women living with HIVIAIDS.

\section{Materials and Methods}

This study used a cross-sectional approach. The inclusion criteria included in this study were female health cadres, active in the community in the past 3 months, Muslim, had exposure to HIVIAIDS material, and lived permanently in the Kudus area. The sample size is calculated based on the table of determining the number of samples from Isaac and Michael at an error rate of $5 \%$ from the target population of 180 people. We involved 119 HIVIAIDS cadres including local residents who care about AIDS (WPA, $n=90$ ), facilitators of families of hope ( $\mathrm{PKH}, \mathrm{n}=17)$, and peer support groups (KDS, $n=12$ ). Data collection was carried out from February to April 2020, the sample was selected using multistage cluster sampling in Kudus Regency, Central Java, Indonesia.

The research instrument consisted of cadre's demographic sheets, nurse support, empowerment of HIVIAIDS health cadres, and the ability of cadres to assist the needs of HIVIAIDS women. The questionnaire was modified from an existing instrument and has met the convergent validity test. Overall indicators of all variables produce cross-loading $>0.5$ and average variance extracted (AVE > 0.5) value. The cross-loading and AVE of each instrument are as follows: Nurse support on informative indicators $=0.847$; emotional $=0.774$; instrumental=0.944; and affiliation=0.874 (AVE =0.743). The results showed that the effects of empowerment of HIV/ AIDS health cadres on the indicators of connectivity with health services $(0.796)$, self actualization (0.685), and appreciate diversity (0.767) with AVE value of 0.563. Meanwhile, the findings showed the effects of ability of HIVIAIDS health cadres on the indicators of accompanying physical needs (0.930), accompanying emotional needs (0.934), assisting social needs (0.970), and accompanying spiritual needs (0.962), with AVE value of 0.901).

The instrument used has also been tested for construct reliability. If composite reliability $>0.7$ and Cronbach alpha $>0.6$, then the construct is declared reliable [11]. Composite reliability and Cronbach alpha values for each variable were nurse support $(0.884$; $0.920)$, cadre empowerment $(0.613 ; 0.794)$, and the ability of HIVIAIDS health cadres $(0.964 ; 0.973)$. Thus, all indicators are declared reliable in measuring the variables.

Data were analyzed descriptively and inferentially using the Statistical Package for the Social Science (SPSS), Version 22 (Armonk, NY: IBM Corp). The level of significance was set at $p<0.05$. Descriptive analysis (mean, frequency, standard deviation, and percentage) was used to describe the univariate characteristics. Multiple linear regression analysis was conducted to determine the support of nurses, empowerment of HIVIAIDS cadres, and its effect on the ability of cadres in assisting women with HIVIAIDS. 
This research has received ethical approval from the Ethics Committee of the Faculty of Nursing, Airlangga University with Ethical Approval No. 1907-KEPK. Complete information about the aims and objectives of the study is explained in advance and the subject has the right to accept or refuse to be involved in this study by giving informed consent.

\section{Results}

Nurses provide informational, emotional, instrumental, and affiliation support to HIVIAIDS cadres from WPA, PKH, and KDS elements in Kudus Regency, as shown in Table 1.

Table 1: Description of nurse support variables on elements of HIVIAIDS health cadres in Kudus Regency in 2020 ( $n=119)$

\begin{tabular}{lccccc}
\hline Indicator & Mean & Median & SD & Min-max & $\mathrm{Cl} 95 \%$ \\
\hline Information & & & & & \\
PKH & 8.00 & 8 & 2.26 & $4-12$ & $6.84-9.16$ \\
WPA & 8.57 & 9 & 3.91 & $3-15$ & $7.75-9.39$ \\
KDS & 7.67 & 6 & 3.93 & $4-15$ & $5.16-10.17$ \\
Emotional & & & & & \\
PKH & 17.94 & 17 & 2.98 & $14-22$ & $16.40-19.48$ \\
WPA & 17.68 & 18 & 3.64 & $9-24$ & $16.91-18.44$ \\
KDS & 16.08 & 16 & 2.64 & $11-20$ & $14.40-17.76$ \\
Instrumental & & & & & \\
PKH & 6.12 & 6 & 1.86 & $3-9$ & $5.16-7.08$ \\
WPA & 5.39 & 5 & 2.78 & $2-10$ & $4.81-5.97$ \\
KDS & 4.67 & 4 & 2.22 & $2-8$ & $3.25-6.08$ \\
Affiliate & & & & & \\
PKH & 9.65 & 10 & 2.62 & $5-14$ & $8.30-10.99$ \\
WPA & 8.04 & 8 & 3.46 & $3-15$ & $7.32-8.77$ \\
KDS & 5.42 & 5 & 2.77 & $3-12$ & $3.65-7.18$ \\
\hline
\end{tabular}

Information: PKH: Family hope facilitators, WPA: Local residents who care for AIDS, KDS: Peer support groups. HIV/AIDS: Human immunodeficiency virus/acquired immune deficiency syndrome.

Table 1 shows that the information support from nurses received by WPA is the highest. $\mathrm{PKH}$ received the highest emotional, instrumental, and affiliation support. Meanwhile, the support for KDS in all indicators including informative, emotional, instrumental values has the lowest weight.

Table 2 shows that most of the respondents have facilitation of information transformation from nurses in the low category (42.9\%). Most of the respondents received the attention of nurse assistance to cadres in carrying out their duties in the medium category $(57.1 \%)$. Then, most of the assistance to cadres was in the form of goods or equipment to support cadre activities in the low category (40.3\%). Most of the respondents considered the award affiliation in the low category or less (47.9\%). Most indicators of empowerment of HIVIAIDS health cadres are in the medium category. However, connectedness to health services including responsibilities, task demands, and relationship harmony is still low $(15.1 \%)$. Most of the respondents have the ability to assist the physical, emotional, social, and spiritual needs of women with HIVIAIDS which is still in the low category.

Table 3 shows the results of the R-square research of 0.28 which means that nurse support and empowerment of health cadres affect the value
Table 2: Statistical description of the dependent and independent variables

\begin{tabular}{|c|c|c|}
\hline Indicator & Frequency & Percentage \\
\hline \multicolumn{3}{|c|}{$\begin{array}{l}\text { Nurse support } \\
\text { Informative }\end{array}$} \\
\hline High & 32 & 26.9 \\
\hline Medium & 36 & 30.3 \\
\hline Low & 51 & 42.9 \\
\hline \multicolumn{3}{|l|}{ Emotional } \\
\hline High & 44 & 37.0 \\
\hline Medium & 68 & 57.1 \\
\hline Low & 7 & 5.9 \\
\hline \multicolumn{3}{|l|}{ Instrumental } \\
\hline High & 37 & 31.1 \\
\hline Medium & 34 & 28.6 \\
\hline Low & 48 & 40.3 \\
\hline \multicolumn{3}{|l|}{ Affiliation } \\
\hline High & 29 & 24.4 \\
\hline Medium & 33 & 27.7 \\
\hline Low & 57 & 47.9 \\
\hline \multicolumn{3}{|c|}{ Empowerment of HIVIAIDS cadres } \\
\hline \multicolumn{3}{|c|}{ Connectivity to health services } \\
\hline Low & 18 & 15.1 \\
\hline Medium & 94 & 79.0 \\
\hline High & 7 & 5.9 \\
\hline \multicolumn{3}{|c|}{ Self-actualization } \\
\hline Low & 2 & 1.7 \\
\hline Medium & 89 & 74.8 \\
\hline High & 28 & 23.5 \\
\hline \multicolumn{3}{|c|}{ Appreciate diversity } \\
\hline Medium & 115 & 96.6 \\
\hline High & 4 & 3.4 \\
\hline \multicolumn{3}{|c|}{ Ability of HIVIAIDS cadres in mentoring women with HIVIAIDS } \\
\hline \multicolumn{3}{|c|}{ Physical needs } \\
\hline Low & 47 & 39.5 \\
\hline Medium & 31 & 26.1 \\
\hline High & 41 & 34.5 \\
\hline \multicolumn{3}{|c|}{ Emotional needs } \\
\hline Low & 58 & 48.7 \\
\hline Medium & 25 & 21.0 \\
\hline High & 36 & 30.3 \\
\hline \multicolumn{3}{|c|}{ Social needs } \\
\hline Low & 60 & 50.4 \\
\hline Medium & 35 & 29.4 \\
\hline High & 24 & 20.2 \\
\hline \multicolumn{3}{|c|}{ Spiritual needs } \\
\hline Low & 47 & 39.5 \\
\hline Medium & 30 & 25.2 \\
\hline High & 42 & 35.3 \\
\hline
\end{tabular}

of the ability of HIVIAIDS cadres in assisting women with HIVIAIDS by $28 \%$. Based on the results of the regression test, it can be concluded that the formula for the regression test model is $Y=-97.080+0.738 X$ $+1.944 \mathrm{X}_{2}$ meaning: (1) The constant of -97.080 states that if there is no $X_{1}$ and $X_{2}$, then the cadre's ability level is -97.080 ; (2) the $X_{1}$ regression coefficient of 0.738 states that every 1 point increase in the value of nurse support will increase the ability of cadres by $73.8 \%$; and (3) the $X_{2}$ regression coefficient of 1.944 states that every 1 point increase in the value of cadre empowerment will increase the capacity of cadres by $194.4 \%$. The model formula can be accepted because it has fulfilled the multiple linear regression assumption test.

\section{Discussion}

The findings of this study indicate that the four types of nurse support may be interrelated and are generally still low in the process of empowering HIV/ AIDS cadres. Emotional support from nurses seems to be the beginnings of a partnership for the community 
Table 3: Statistical description of the regression of nurse support, empowerment of HIVIAIDS cadres, and the ability of HIVIAIDS cadres to assist women with HIVIAIDS

\begin{tabular}{|c|c|c|c|c|c|c|c|}
\hline \multicolumn{8}{|l|}{ Model summary ${ }^{\mathrm{b}}$} \\
\hline Model & $\mathrm{R}$ & R square & Adjusted R square & Std. error of the estimate & \multicolumn{3}{|c|}{ Durbin-Watson } \\
\hline 1 & $0.529^{\mathrm{a}}$ & 0.280 & 0.267 & 33.309 & \multicolumn{3}{|c|}{1.341} \\
\hline \multicolumn{8}{|c|}{$\begin{array}{l}\text { a. Predictors: (Constant), cadre's empowerment, nurse's support } \\
\text { b. Dependent variable: The abilities of the cadres }\end{array}$} \\
\hline \multicolumn{8}{|l|}{ ANOVA $^{a}$} \\
\hline Model & Sum of squares & df & Mean square & $\mathrm{F}$ & \multicolumn{3}{|l|}{ Sig. } \\
\hline \multicolumn{8}{|l|}{1} \\
\hline Regression & $50,007.426$ & 2 & $25,003.713$ & 22.536 & \multirow{2}{*}{\multicolumn{3}{|c|}{$0.000 \mathrm{~b}$}} \\
\hline Residual & $128,701.364$ & 116 & 1109.495 & & & & \\
\hline Total & $178,708.790$ & 118 & & & & & \\
\hline \multirow{2}{*}{\multicolumn{8}{|c|}{$\begin{array}{l}\text { a. Dependent variable: The abilities of the cadres } \\
\text { b. Predictors: (Constant), cadre's empowerment, nurse's support }\end{array}$}} \\
\hline & & & & & & & \\
\hline \multicolumn{8}{|c|}{ Coefficients $^{\mathrm{a}}$} \\
\hline \multirow[t]{2}{*}{ Model } & \multicolumn{2}{|c|}{ Unstandardized coefficients } & Standardized coefficients & $\mathrm{t}$ & Sig. & \multicolumn{2}{|c|}{$95.0 \%$ confidence interval for B } \\
\hline & $\mathrm{B}$ & Std. error & Beta & & & Lower bound & Upper bound \\
\hline \multicolumn{8}{|r|}{ 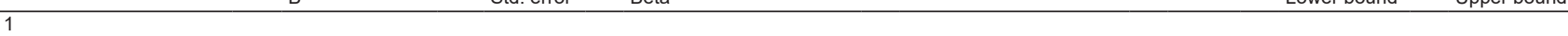 } \\
\hline (Constant) & -97.080 & 33.097 & & -2.933 & 0.004 & -162.633 & -31.528 \\
\hline Nurse's support & 0.738 & 0.304 & 0.215 & 2.428 & 0.017 & 0.136 & 1.340 \\
\hline Cadre's empowerment & 1.944 & 0.438 & 0.394 & 4.441 & 0.000 & 1.077 & 2.811 \\
\hline
\end{tabular}

empowerment process by helping HIVIAIDS cadres feel there are care, concern, and trust. Particular attention is paid to considering additional resources that cadres may need to strengthen their role in the community so that the ability of cadres in mentoring needs of women living with HIVIAIDS can be explored optimally.

Emotional support is very important as a pathway to benefiting from informational and instrumental support sources [12]. Lack of attention, appreciation, and control to cadre creates feelings of frustration and makes cadre even more powerless [1]. Improper relationship with the health system and inadequate continuously support can hinder the empowerment process, so making team-based care ineffective [13].

Program sustainability requires the facilitation of consistent and adequate supervision of HIVIAIDS cadres through high-quality routine supervision, transformation, and intensive assistance from health workers to maintain the performance of cadres [13], [14]. In addition, program sustainability includes the support for providing work aids, standard procedure manuals and refresher training. Cadres work to serve vulnerable population in community. Almost half of them reported more work interactions with nurses than doctors $(49.7 \%$ vs. $46.2 \%)$ [16].

As an effort to creating a positive work environment and right relationship, it can be developed by having a sense of empathy. Empathy for cadres means treating each other with respect and anticipating the needs of others [17]. Nurse is expected to work to empower the community, more than the facilitated capacity building of cadre. Hence, they are able to promote positive behavior and carry out their social roles in the community.

Health services for people at risk of being infected with viruses that weaken the human immune system/HIV have become one of the basic services in the minimum service standards for district/city health. This is in accordance with Minister of Health Regulation No. 4 of 2019. It is stated that nurses have the task of providing services for HIV testing, care for PLWHA and referrals to higher-level health services, assisting HIVI AIDS cadres with monitoring and evaluation, facilitating communities to become empowered, transforming cadres, and motivating community mobilization.

Lack of partnership was identified as one of the barriers to collaboration between primary health care and local community health services [18]. Health workers tend to shift tasks in an informal and less clear way [4]. Supposedly, the shifting of the task of providing HIV services is carried out by having prepared focused interventions, careful planning, and consideration of holistic and contextual factors [4].

The core elements of cadres are social networks, social support, trust, and broad community participation [19]. Trust is built on accountability, integrity, and loyalty at all levels of the organization. Hence, cadre competence is very important for individual cadres to build public trust. Empowerment of HIVIAIDS health cadres is influenced by the strongest factor from personal resources [10]. The consistency and empowerment that form the basis for shared governance help build trust in leaders and stakeholders. The cadres' self-capacity is built through education or open exchange of ideas through critical dialogue and critical thinking reflection. The ability of cadres to mentoring people with HIVIAIDS in meeting their physical, emotional, social, and spiritual needs is an indicator of the competence of HIVIAIDS health cadres.

The purpose of assisting cadres to meet physical needs is to maintain a healthy physical condition, increase CD4 cell count, and undetectable viral load. The existence of emotional problems can damage the quality of life of PLWHA including stigmatization [20]. Special attention to psychological interventions and coping strategies is important to do to alleviate the suffering of women with HIVIAIDS, maintain mental health, and improve their well-being [21]. PLWHA also experience social problems, such as difficulty finding someone to discuss their illness with due to the 
self-stigma of HIV. The problem of disclosure by HIV women has psychosocial factors that impact their ability to maintain health and well-being [22]. In Indonesia, this is a major problem for PLWHA. HIVIAIDS health cadres as companions must have spiritual values to love others, be non-judgmental, accept them as they are, empathy, respect, and tolerance [23]. The spirituality of cadres in general aims to support and helps reduce the concerns of PLWHA and makes them aware of their illness so that it is hoped that it will improve the lives of PLWHA. Community interventions have been shown to help HIV-positive women reduce self-stigma and develop effective means of status disclosure [24].

Mentoring the needs of women with HIVIAIDS is potentially carried out by WPA cadres, strengthening cadres from the previous peer support group (KDS) element, which had a very limited number of $12 \%$ of 119 respondents. Hence, the ratio is not balanced with the number of PLWHA which tends to increase year by year. This condition is almost the same in several countries, public awareness is still limited among fellow sufferers or peer support groups [25]. The participation and support of the wider community from elements of influential people such as community leaders, closed people, and spiritual leaders were still low [26], [27], [28]. Community involvement programs are still segmented, not comprehensively addressing the problems of PLWHA. Some of them include mobilizing the community, reducing the rate of loss to follow-up ART treatment, meeting emotional needs, physical needs, psychological interventions, and coping strategies [20], [21], [27], [29].

Nurse support is needed in the process of relations or partnerships between cadres and the health care system. In accordance with the nursing paradigm in the Rogerian Science of Unitary Human Beings [30] that health care focuses on maximizing one's strengths and minimizing weaknesses. Nurses facilitate the ability of cadres and empower them to participate intentionally in achieving meaningful goals. In addition, the facilitation includes making changes and providing knowledge directly in shared situations.

\section{Conclusion}

Nurse support on empowerment HIVIAIDS health cadre was low in informational, emotional, instrumental, and affiliation aspects. Cadre needs a work guidelines book, attention, empathy, appreciation, and equipment support in carrying out tasks in the community to improve the performance of cadres. The existence of HIVIAIDS health cadres is able to bridge the gap between health care and the community by providing health education that is appropriate to the local cultural context, assisting the needs of vulnerable groups of people with HIVIAIDS, and coordinating care for people with complex needs. The role of nurses in empowering cadres is as great as health workers who directly interact with the community. Health nurses at Community Health Centers (Puskesmas) services as stakeholders can combine cadres as members of the care team provide support and ensure empowerment goes well. Nurse support can be realized if simultaneously, there are efforts to strengthen the health system itself with the synergy of stakeholders in addressing HIVIAIDS issues as regional health issues and strengthening the regulatory function through the development of operational policies at the Community Health Center (Puskesmas) level.

\section{References}

1. Kane S, Kok M, Ormel H, Otiso L, Sidat M, Namakhoma I, et al. Limits and opportunities to community health worker empowerment: A multi-country comparative study. Soc Sci Med. 2016;164:27-34.

PMid:27459022

2. Mcpake B, Edoka I, Witter S, Kielmann K, Taegtmeyer M, Dieleman $\mathrm{M}$, et al. Cost-effectiveness of community-based practitioner programmes in Ethiopia, Indonesia and Kenya. Bull World Health Organ. 2015;93(9):631A-9.

PMid:26478627

3. Brunton G, Thomas J, Mara-Eves AO, Jamal F, Oliver S, Kavanagh J. Narratives of community engagement: A systematic review-derived conceptual framework for public health interventions. BMC Public Health. 2017;17(1):944. https://doi.org/10.1186/s12889-017-4958-4

PMid:29228932

4. Mundeva H, Snyder J, Ngilangwa DP, Kaida A. Ethics of task shifting in the health workforce : Exploring the role of community health workers in HIV service delivery in low-and middleincome countries. BMC Med Ethics. 2018;19(1):71. https://doi. org/10.1186/s12910-018-0312-3

PMid:29973217

5. Modi S, Callahan T, Rodrigues J, Kajoka MD, Dale HM, Langa JO, et al. Overcoming health system challenges for women and children living with HIV through the global plan. J Acquir Immune Defic Syndr. 2017;75(1):76-85. PMid:28399000

6. Seutloali T, Napoles L, Bam N. Community health workers in Lesotho : Experiences of health promotion activities. Afr J Prim Health Care Fam Med. 2018;10(1):e1-8. https://doi.org/10.4102/ phcfm.v10i1.1558

PMid:29781677

7. Relf MV, Booth C, Mallinson RK, Powell D, Yu-Shears J. Essential nursing competencies related to HIV and AIDS. J Assoc Nurses AIDS Care. 2011;22(1):e5-40. https://doi. org/10.1016/j.jana.2010.07.007 PMid:21168066

8. Anderson ET, McFarlan J. Community as Parter Theory and Practice in Nursing. $6^{\text {th }}$ ed. United States: Lippincott Williams; 2011.

9. Shearer NB. Health empowerment theory as a guidefor practice. Geriatr Nurs. 2009;30(2):4-10. 


\section{PMid: 19345857}

10. Nursalam N, Ernawati E, Devy SR, Efendi F. Model for development of community health care as partners on stigma and quality of living women with hiv/aids. Sys Rev Pharm. 2020;11(6):1095-9.

11. Hair JF, Hult GT, Ringle CM, Sarstedt M. A Primer on Partial Least Squares Structural Equation Modeling (PLS-SEM). $2^{\text {nd }}$ ed., Vol. 38. United States: SAGE; 2017. https://doi. org/10.3926/oss.37

12. Houston E, Osborn A, Lyons T, Masvawure T, Raja S. Exploring perceived social support from peer facilitators in an HIV treatment adherence intervention for african american patients : A content analysis of participant perspectives. J Community Appl Soc Psychol. 2015;501:487-501. https://doi.org/10.1002/ casp. 2228

13. De Neve JW, Boudreaux C, Gill R, Geldsetzer P, Vaikath M, Bärnighausen $\mathrm{T}$, et al. Harmonizing community-based health worker programs for HIV: A narrative review and analytic framework. Hum Resour Health. 2017;15(1):1-10. https://doi. org/10.1186/s12960-017-0219-y

14. Kawakatsu Y, Sugishita T, Tsutsui J, Oruenjo K, Wakhule S, Kibosia K, et al. Individual and contextual factors associated with community health workers' performance in Nyanza Province, Kenya : A multilevel analysis. BMC Health Serv. Res. 2015;15:1-10. https://doi.org/10.1186/s12913-015-1117-4

15. Busza J, Dauya E, Bandason T, Simms V, Chikwari CD, Makamba $\mathrm{M}$, et al. The role of community health workers in improving HIV treatment outcomes in children: Lessons learned from the ZENITH trial in Zimbabwe. Health Policy Plan. 2018;33(3):328-34. https://doi.org/10.1093/heapol/czx187 PMid:29309578

16. Allen CG, Escoffery C, Satsangi A, Brownstein JN. Strategies to improve the integration of community health workers into health care teams: A little fish in a big pond. Prev Chronic Dis. 2015;12(9):1-10. https://doi.org/10.5888/pcd12.150199 PMid:26378900

17. Christina D, Reilly BA. Nurse engagement: What are the contributing factors for success? Omline $\mathrm{J}$ Issues Nurs. 2016;21(1):2.

PMid:27853182

18. Pratt R, Gyllstrom B, Gearin K, Lange C, Hahn D, Baldwin LM, et al. Identifying barriers to collaboration between primary care and public health: Experiences at the local level. Public Health Rep. 2018;133(3):311-7. https://doi. org/10.1177/0033354918764391 PMid:29614236

19. Xie F, Zheng H, Huang L, Yuan Z, Lu Y. Social capital associated with quality of life among people living with HIV/ AIDS in nanchang, China. Int $\mathrm{J}$ Environ Res Public Health. 2019;16(2):1-12. https://doi.org/10.3390/ijerph16020276 PMid:30669364

20. Das MB, Sheshaadhiri TK, Nageshwar DN. Emotional challenges faced by people with HIVIAIDS (PWHA). Int Educ Res J. 2017;3(5):60-3.

21. Nobre N. HIV-related self-stigma and health-related quality of life of people living with HIV in Finland. J Assoc Nurses AIDS Care. 2018;29(2):254-65. https://doi.org/10.1016/j.jana.2017.08.006 PMid:28935441

22. Hughes C, Croston M. Psychosocial factors that impact maintaining health and wellbeing in women over 50 years living with hiv: A systematic review. HIV Nurs. 2020;20(2):32-42.

23. Shaw SA, Saifi R, Lim SH, Saifuddeen SM. Islam and HIV related social services in Malaysia. J Relig Spiritual Soc Work Soc Thought. 2017;36(1-2):133-45. https://doi.org/10.1080/154 26432.2017.1300078

24. Wang K, Chen W, Zhang L, Bao M, Zhao H, Lu H. Facilitators of and barriers to HIV self-management: Perspectives of HIVpositive women in China. Appl Nurs Res. 2016;32:91-7. https:// doi.org/10.1016/j.apnr.2016.06.004

PMid:27969059

25. Bateganya MH, Amanyeiwe U, Roxo U, Dong M. Impact of support groups for people living with HIV on clinical outcomes. J Acquir Immune Defic Syndr. 2015;68(3):S368-74. https://doi. org/10.1097/qai.0000000000000519

PMid:25768876

26. Prinsloo CD. A community "Hub" network intervention for HIV stigma reduction: A case study. J Assoc Nurses AIDS Care. 2015;27(2):166-79. https://doi.org/10.1016/j.jana.2015.10.007 PMid:26627447

27. Angula P, Ncama BP. Guidelines for community-based HIV/ AIDS stigma reduction intervention in a rural community. World $J$ AIDS. 2016;6(1):27-36. https://doi.org/10.4236/wja.2016.61004

28. Kruger G, Greeff M, Letsosa R. Spiritual leaders' experiences of a comprehensive HIV stigma reduction intervention. Herv Teol Stud. 2018;74(4):1-10. https://doi.org/10.4102/hts.v74i4.4875

29. Mutagoma M, Sebuhoro D, Nyemazi JP, Mills EJ, Forrest JI, Remera $\mathrm{E}$, et al. The role of community health workers and local leaders in reducing attrition among participant in the AIDS indicator survey and HIV incidence in a national cohort study in Rwanda. BMC Public Health. 2018;18(1):338. https://doi. org/10.1186/s12889-018-5243-x PMid:29523102

30. Alligood MR. Nursing Theory Utilization and Application. $5^{\text {th }}$ ed. United States: Elsevier, Mosby; 2014. 